Relations industrielles

Industrial Relations

\title{
Index — volume $49-1994$
}

Volume 49, numéro 4, 1994

Syndicats et restructuration économique

Unions and Economic Restructuring

URI : https://id.erudit.org/iderudit/050988ar

DOI : https://doi.org/10.7202/050988ar

Aller au sommaire du numéro

\section{Éditeur(s)}

Département des relations industrielles de l'Université Laval

ISSN

0034-379X (imprimé)

1703-8138 (numérique)

Découvrir la revue

Citer ce document

(1994). Index - volume 49-1994. Relations industrielles / Industrial Relations, 49(4), 892-909. https://doi.org/10.7202/050988ar

Tous droits réservés (C) Département des relations industrielles de l'Université Laval, 1994
Ce document est protégé par la loi sur le droit d'auteur. L'utilisation des services d'Érudit (y compris la reproduction) est assujettie à sa politique d'utilisation que vous pouvez consulter en ligne.

https://apropos.erudit.org/fr/usagers/politique-dutilisation/ 


\section{INDEX - VOL. 49 - 1994}

\section{Index alphabétique des articles}

Alphabetical Index of Articles

Accréditation syndicale en Colombie-Britannique, Délais de l', Richard Holmes et Robert Rogow, $\mathrm{n}^{\circ} 1$

Aide demandée : propension à travailler pour le syndicat, Sarosh Kuruvilla et Jack Fiorito, ${ }^{\circ} 3$

$574-576$

ALENA et le pouvoir des mouvements syndicaux au Canada et aux États-Unis, L', Ian Robinson, $\mathrm{n}^{\circ} 4$

Alimentation au détail au Québec, Perceptions et attitudes à l'égard des ressources humaines: le cas de l', René Blais, $\mathrm{n}^{\circ} 2$.

Allemande et quelques éléments de prospective, La déréglementation à $l$ ', Berndt Keller, $\mathrm{n}^{\circ} 2$

$278-281$

Arbitrage de grief? L'expérience de Terre-Neuve, La présence d'avocats influence-t-elle les résultats en, Kenneth Wm. Thornicroft, $\mathrm{n}^{\circ} 2$

Aspects économiques de la santé et sécurité au travail, Paul Lanoie, $\mathrm{n}^{\circ} 1$

Barbash, 1911-1994, A Tribute to Jack, Thomas A. Kochan, $\mathrm{n}^{\circ} 3$. Barbash, 1911-1994, Hommage à Jack, Jean Sexton, n 3.

Bargaining and Worker Representation Under New Zealand's Employment Contracts Legislation : A Review After Two Years, Raymond Harbridge and Kevin Hince, $n^{\circ} 3$

$576-594$

Blue-Collar Employees' Compensation in Québec Municipalities, The Determinants of, Michel Tremblay and Denis Marcoux, $\mathrm{n}^{\circ} 3$

$545-548$

Britain Since 1979, The Politics of Restructuring : Trade Unions on the Defensive in, Jeremy Waddington and Colin Whitston, $\mathrm{n}^{\circ} 4$.

British Columbia, Time to Certification of Unions in, Richard Holmes and Robert Rogow, $\mathrm{n}^{\circ} 1$

$794-819$

Cadres: l'importance de la carrière, Facteurs explicatifs des intention de quitter des, Thierry Wils, Tania Saba et Gilles Guérin, $\mathrm{n}^{\circ} 1$

CAMI, L'engagement du travailleur, les relations du travail et la production allégée à l'usine, James Rinehart, Christopher Huxley et David Robertson, $n^{\circ} 4$ 
CAMI, Worker Commitment and Labour Management Relations under Lean Production at, James Rinehart, Christopher Huxley and David Robertson, $\mathrm{n}^{\circ} 4$

$750-773$

Canada and the United States, Measures of Excess Demand and Unemployment in, Calvin D. Siebert and Mahmood A. Zaidi, $\mathrm{n}^{\circ} 3$

$503-526$

Canada and the United States, NAFTA, Social Unionism, and Labour Movement Power in, Ian Robinson, $\mathrm{n}^{\circ} 4$

Canada et aux États-Unis, Demande excédentaire et chômage au, Calvin D. Siebert et Mahmood A. Zaidi, $\mathbf{n}^{\circ} 3$

$526-528$

Canada et aux États-Unis, L'ALENA et le pouvoir des mouvements syndicaux au, Ian Robinson, $\mathrm{n}^{\circ} 4$

$693-696$

Careers in Management, Of Mommy Tracks and Glass Ceilings : A

Case Study of Men's and Women's, Alison M. Konrad and Kathy Cannings, $\mathrm{n}^{\circ} 2$

Certification of Unions in British Columbia, Time to, Richard Holmes and Robert Rogow, $\mathrm{n}^{\circ} 1$

Chômage au Canada et aux États-Unis, Demande excédentaire et,

Calvin D. Siebert et Mahmood A. Zaidi, $n^{\circ} 3$

$526-528$

Civil Code of Québec and the Labour Standards Act, The, Jean-Yves

Brière, $\mathrm{n}^{\circ} 1$

Client Satisfaction. The Impact of the Decentralization of Human

Resources Services on, Thierry Wils, Marcel Saint-Onge and

Christiane Labelle, $\mathrm{n}^{\circ} 3$.

$501-503$

Code civil du Québec et la Loi sur les normes du travail : conver-

gence ou divergence?, Le, Jean-Yves Brière, $\mathrm{n}^{\circ} 1$

$104-131$

Code civil du Québec, Effets combinatoires de deux codes : Code du

travail et, Fernand Morin, $\mathrm{n}^{\circ} 2$

Code du travail et Code civil du Québec, Effets combinatoires de deux codes, Fernand Morin, $\mathrm{n}^{\circ} 2$.

$227-248$

Collective Bargaining and Management of Employment Relations in

France, Decentralization of, Liem Hoang-Ngoc and Michel

Lallement, $n^{\circ} 3$

$463-465$

Collective Bargaining in the Quebec Paper Industry, Recent Trends in, Reynald Bourque and Claude Rioux, $n^{\circ} 4$

$748-750$

Colombie-Britannique, Délais de l'accréditation syndicale en,

Richard Holmes et Robert Rogow, $\mathrm{n}^{\circ} 1$

$150-152$

Combined Effects of the New Québec Civil Code and the Québec

Labour Code, The, Fernand Morin, $\mathrm{n}^{\circ} 2$.

Commitment and Labour Management Relations under Lean Production at CAMI, Worker, James Rinehart, Christopher Huxley and David Robertson, $n^{\circ} 4$ 
Compensation in Québec Municipalities, The Determinants of BlueCollar Employees', Michel Tremblay and Denis Marcoux, $\mathrm{n}^{\circ} 3$. Confiance, coopération et partenariat : un processus de transformation dans l'entreprise québécoise, Denis Harrisson et Normand Laplante, $n^{\circ} 4$.

$545-548$

$696-728$

Confidence, Cooperation and Partnership: A Process of Transformation in Quebec Firms, Denis Harrisson and Normand Laplante, $\mathrm{n}^{\circ} 4$

Cooperation and Partnership: A Process of Transformation in Quebec Firms, Confidence, Denis Harrisson and Normand Laplante, $\mathrm{n}^{\circ} 4$

Coopération et partenariat: un processus de transformation dans l'entreprise québécoise, Confiance, Denis Harrisson et Normand Laplante, $\mathrm{n}^{\circ} 4$

Crise économique: réponses à la restructuration, Les dirigeants syndicaux et la, Norene Pupo et Jerry White, $n^{\circ} 4$

Décentralisation des relations professionnelles et gestion de l'emploi en France, Liem Hoang-Ngoc et Michel Lallement, $\mathrm{n}^{\circ} 3$. Décentralisation des services de ressources humaines : impacts sur la satisfaction des clients, Thierry Wils, Marcel Saint-Onge et Christiane Labelle, $\mathrm{n}^{\circ} 3$

Decentralization of Collective Bargaining and Management of Employment Relations in France, Liem Hoang-Ngoc and Michel Lallement, $\mathrm{n}^{\circ} 3$

$463-465$

Decentralization of Human Resources Services on Client Satisfaction, The Impact of the, Thierry Wils, Marcel SaintOnge and Christiane Labelle, $\mathrm{n}^{\circ} 3$

Délais de l'accréditation syndicale en Colombie-Britannique, Richard Holmes et Robert Rogow, $\mathrm{n}^{\circ} 1$

Demande excédentaire et chômage au Canada et aux États-Unis, Calvin D. Siebert et Mahmood A. Zaidi, $\mathrm{n}^{\circ} 3$ 844-846 $441-463$ $(63-465$

$501-503$

$150-152$

$526-528$

Demi-siècle de relations industrielles à l'Université Laval, Un, Gilles Laflamme, $\mathrm{n}^{\circ} 1$

Déréglementation à l'allemande et quelques éléments de prospective, La, Berndt Keller, $\mathrm{n}^{\circ} 2$

$278-281$

Deregulation - And Beyond, The German Version of, Berndt Keller, $\mathrm{n}^{\circ} 2$

Determinants of Blue-Collar Employees' Compensation in Québec Municipalities, The, Michel Tremblay and Denis Marcoux, $\mathrm{n}^{\circ} 3$. Determinants of Propensity to Unionize in the Private Service Sector, Jean-Guy Bergeron, $n^{\circ} 4$. 
Dirigeants syndicaux et la crise économique : réponses à la restructuration, Les, Norene Pupo et Jerry White, $n^{\circ} 4$

Discrimination et vie familiale: une étude de cas des carrières des hommes et des femmes en gestion, Alison M. Konrad et Kathy Cannings, $\mathrm{n}^{\circ} 2$

Economic Crisis: Responses to Restructuring, Union Leaders and the, Norene Pupo and Jerry White, $\mathrm{n}^{\circ} 4$....

Economic Restructuring: Introduction, Unions and, Jacques Bélanger and Gregor Murray, $n^{\circ} 4$

Effets combinatoires de deux codes: Code du travail et Code civil du Québec, Fernand Morin, $\mathrm{n}^{\circ} 2$

Élections syndicales, Une vérification de la théorie intégrative de

Wheeler lors de six, Hoyt N. Wheeler, John A. McClendon et Roger D. Weikle, $\mathrm{n}^{\circ} 3$.

Employer Responses to Workers' Compensation Insurance Experience Rating, Boris Kralj, $\mathrm{n}^{\circ} 1$

Employers' Associations in the Province of Québec: A Diversity,

François Delorme, Régis Fortin and Louis Gosselin, $\mathbf{n}^{\circ} 1$.

Employés manuels dans les municipalités québécoises, Étude des déterminants de la rémunération des, Michel Tremblay et Denis Marcoux, $\mathrm{n}^{\circ} 3$

Employeurs, La tarification par incidence - réactions des, Boris Kralj, ${ }^{\circ} 1$

Employment Relations in France, Decentralization of Collective Bargaining and Management of , Liem Hoang-Ngoc and Michel Lallement, $n^{\circ} 3$

Engagement du travailleur, les relations du travail et la production allégée à l'usine CAMI, L', James Rinehart, Christopher Huxley et David Robertson, $n^{\circ} 4$

$773-776$

Entreprise québécoise, Confiance, coopération et partenariat: un processus de transformation dans l', Dennis Harrisson et Normand Laplante, $n^{\circ} 4$

États-Unis, Demande excédentaire et chômage au Canada et aux,

Calvin D. Siebert et Mahmood A. Zaidi, $n^{\circ} 3$

États-Unis, L'ALENA et le pouvoir des mouvements syndicaux au Canada et aux, Ian Robinson, $n^{\circ} 4$ 693-696

Étude des déterminants de la rémunération des employés manuels dans les municipalités québécoises, Michel Tremblay et Denis Marcoux, $\mathrm{n}^{\circ} 3$

Excess Demand and Unemployment in Canada and the United States. Measures of, Calvin D. Siebert and Mahmood A. Zaidi, $n^{\circ} 3$ 
Facteurs explicatifs de la propension à se syndiquer dans les services privés, Les, Jean-Guy Bergeron, $\mathrm{n}^{\circ} 4$.....

$776-792$

Facteurs explicatifs des intentions de quitter des cadres: l'importance de la carrière, Thierry Wils, Tania Saba et Gilles Guérin, $\mathrm{n}^{\circ} 1$

Firms, Confidence, Cooperation and Partnership: A Process of Transformation in Quebec, Denis Harrisson and Normand Laplante, $n^{\circ} 4$

France, Décentralisation des relations professionnelles et gestion de l'emploi en, Liem Hoang-Ngoc et Michel Lallement, $\mathrm{n}^{\circ} 3 \ldots . .$. France, Decentralization of Collective Bargaining and Management of Employment Relations in, Liem Hoang-Ngoc and Michel Lallement, $n^{\circ} 3$.

728-730

$441-463$

German Version of Deregulation - And Beyond, The, Berndt Keller, $\mathrm{n}^{\circ} 2$

$251-278$

Gestion de l'emploi en France, Décentralisation des relations professionnelles et, Liem Hoang-Ngoc et Michel Lallement, $n^{\circ} 3$.

Gestion des ressources humaines: du modèle traditionnel au modèle renouvelé, La, Gilles Guérin et Thierry Wils. Introduction: Michel Audet. Commentaires: Laurent Bélanger, Richard J. Long et Bernard Galambaud (Symposium), $n^{\circ} 1$

$168-188$

Gestion, Discrimination et vie familiale : une étude de cas des carrières des hommes et des femmes en, Alison M. Konrad et Kathy Cannings, $\mathbf{n}^{\circ} 2$

Grande-Bretagne depuis 1979: les syndicats sur la défensive, Les politiques de restructuration en, Jeremy Waddington et Colin Whitston, $n^{\circ} 4$

Grievance Arbitration Outcomes? The Newfoundland Experience, Do Lawyers Affect, Kenneth Wm. Thornicroft, $\mathrm{n}^{\circ} 2$

Half Century of Industrial Relations at Université Laval, A, Gilles Laflamme, $\mathrm{n}^{\circ} 1$

Hommes et des femmes en gestion, Discrimination et vie familiale: une étude de cas des carrières des, Alison M. Konrad et Kathy Cannings, $\mathrm{n}^{\circ} 2$....

Human Resources Services on Client Satisfaction, The Impact of the, Thierry Wils, Marcel Saint-Onge and Christiane Labelle, $n^{\circ} 3$. Human Resources: Retail Food Sales in Québec, Perceptions of and Attitudes Toward, René Blais, $\mathrm{n}^{\circ} 2$

$501-503$

$354-356$

Impact of the Decentralization of Human Resources Services on Client Satisfaction, The, Thierry Wils, Marcel Saint-Onge and Christiane Labelle, $n^{\circ} 3$ 
Industrial Relations at Université Laval, A Half Century of, Gilles Laflamme, $\mathrm{n}^{\circ} 1$

Industrial Relations Theory: Its Nature, Scope, and Pedagogy, Roy J. Adams and Noah M. Melz, eds. Introduction: Jean Boivin, Commentaires: Mark Thompson, Richard B. Peterson, Jean Boivin (Symposium), $\mathrm{n}^{\circ} 2$

Industrie du papier au Québec, Tendances récentes de la négocia. tion collective dans $l$, Reynald Bourque et Claude Rioux, $\mathrm{n}^{\circ} 4$ "Integrative Theory" in Six Union Election Cases, Toward a Test of Wheeler's, Hoyt N. Wheeler, John A. McClendon, and Roger D. Weikle, $\mathrm{n}^{\circ} 3$

Intentions de quitter des cadres: l'importance de la carrière, Facteurs explicatifs des, Thierry Wils, Tania Saba et Gilles Guérin, $\mathrm{n}^{\circ} 1$

Introduction, Syndicats et restructuration économique, Jacques Bélanger et Gregor Murray, $\mathbf{n}^{\circ} 4$

Introduction: Unions and Economic Restructuring, Jacques Bélanger and Gregor Murray, $n^{\circ} 4$

Labour Management Relations under Lean Production at CAMI,

Worker Commitment and, James Rinehart, Christopher Huxley and David Robertson, $\mathrm{n}^{\circ} 4$

Labour Movement Power in Canada and the United States, NAFTA,

Social Unionism, and, Ian Robinson, $\mathrm{n}^{\circ} 4$

Labour Standards Act, The Civil Code of Québec and the, Jean-Yves Brière, $\mathrm{n}^{\mathrm{o}} 1$

Lawyers Affect Grievance Arbitration Outcomes? The Newfoundland Experience, Do, Kenneth $\mathrm{Wm}$. Thornicroft, $\mathrm{n}^{\circ} 2 \ldots .$. Lean Production at CAMI, Worker Commitment and Labour Management Relations under, James Rinehart, Christopher Huxley and David Robertson, ${ }^{\circ} 4$

Local Union Officers' Policies on New Forms of Work Organization,

Paul-André Lapointe and Renaud Paquet, $\mathrm{n}^{\circ} 2$.

Loi néo-zélandaise sur les contrats de travail : bilan après deux années, Négociations salariales et représentation syndicale selon la, Raymond Harbridge et Kevin Hince, $n^{\circ} 3$

$750-773$

$302-303$

Loi sur les normes du travail : convergence ou divergence?, Le Code civil du Québec et la, Jean-Yves Brière, $\mathrm{n}^{\circ} 1$

Management of Employment Relations in France, Decentralization of Collective Bargaining and, Liem Hoang-Ngoc and Michel Lallement, $\mathrm{n}^{\circ} 3$ 
Management, Of Mommy Tracks and Glass Ceilings : A Case Study of Men's and Women's Careers in, Alison M. Konrad and Kathy Cannings, $\mathrm{n}^{\circ} 2$. $303-333$

Measures of Excess Demand and Unemployment in Canada and the United States, Calvin D. Siebert and Mahmood A. Zaidi, $\mathbf{n}^{\circ} 3$. $503-526$ Men's and Women's Careers in Management, Of Mommy Tracks and Glass Ceilings: A Case Study of, Alison M. Konrad and Kathy Cannings, $\mathrm{n}^{\circ} 2$

Mouvements syndicaux au Canada et aux États-Unis, L'ALENA et le pouvoir des, Ian Robinson, $n^{\circ} 4$

Municipalités québécoises, Étude des déterminants de la rémunération des employés manuels dans les, Michel Tremblay et Denis Marcoux, $\mathrm{n}^{\circ} 3$

Municipalities, The Determinants of Blue-Collar Employees' Compensation in Québec, Michel Tremblay and Denis Marcoux, $\mathrm{n}^{\circ} 3$

NAFTA, Social Unionism, and Labour Movement Power in Canada and the United States, Ian Robinson, $\mathrm{n}^{\circ} 4$

Négociation collective dans l'industrie du papier au Québec, Tendances récentes de la, Reynald Bourque et Claude Rioux, $\mathrm{n}^{\circ} 4$

$730-748$

Négociations salariales et représentation syndicale selon la loi néozélandaise sur les contrats de travail : bilan après deux années,

Raymond Harbridge et Kevin Hince, $\mathrm{n}^{\circ} 3$

New Québec Civil Code and the Québec Labour Code, The Combined Effects of the, Fernand Morin, $\mathrm{n}^{\circ} 2$

New Zealand's Employment Contracts Legislation: A Review After

Two Years, Bargaining and Worker Representation Under,

Raymond Harbridge and Kevin Hince, $n^{\circ} 3$

Newfoundland Experience, Do Lawyers Affect Grievance Arbitration Outcomes? The, Kenneth Wm. Thornicroft, $\mathrm{n}^{\circ} 2 \ldots$ Non-syndiqués, La réintégration chez les, Genevieve Eden, $\mathrm{n}^{\circ} 1 \ldots$. Nonunion Sector: An Empirical Analysis, Reinstatement in the, Genevieve Eden, $\mathrm{n}^{\circ} \mathrm{l}$

Of Mommy Tracks and Glass Ceilings : A Case Study of Men's and

Women's Careers in Management, Alison M. Konrad and Kathy

Cannings, $\mathrm{n}^{\circ} 2$

Organisation du monde patronal au Québec : un portrait diversifié,

$L^{\prime}$, François Delorme, Régis Fortin et Louis Gosselin, $\mathbf{n}^{\circ} 1 \ldots$.

Organisation du travail, Les syndicats et les nouvelles formes d',

Paul-André Lapointe et Renaud Paquet, $\mathrm{n}^{\circ} 2$ 
Paper Industry, Recent Trends in Collective Bargaining in the Quebec, Reynald Bourque and Claude Rioux, $\mathrm{n}^{\circ} 4$

Partenariat: un processus de transformation dans l'entreprise québécoise, Confiance, coopération et, Denis Harrisson et Normand Laplante, $n^{\circ} 4$

Partnership: A Process of Transformation in Quebec Firms, Confidence, Cooperation and, Denis Harrisson and Normand Laplante, $\mathrm{n}^{\circ} 4$

Patronal au Québec: un portrait diversifié, L'organisation du monde, François Delorme, Régis Fortin et Louis Gosselin, $\mathrm{n}^{\circ} 1$. Perceptions et attitudes à l'égard des ressources humaines: le cas de l'alimentation au détail au Québec, René Blais, $\mathrm{n}^{\circ} 2$

$696-728$

$728-730$

$336-354$

Perceptions of and Attitudes Toward Human Resources: Retail

Food Sales in Québec, René Blais, $n^{\circ} 2$...

$354-356$

Politics of Restructuring : Trade Unions on the Defensive in Britain

Since 1979, The, Jeremy Waddington and Colin Whitston, $\mathrm{n}^{\circ} 4$. Politiques de restructuration en Grande-Bretagne depuis 1979: les syndicats sur la défensive, Les, Jeremy Waddington et Colin Whitston, $n^{\circ} 4$

Pouvoir des mouvements syndicaux au Canada et aux États-Unis, $L^{\prime} A L E N A$ et le, Ian Robinson, $\mathrm{n}^{\circ} 4$

Power in Canada and the United States, NAFTA, Social Unionism, and Labour Movement, Ian Robinson, $\mathrm{n}^{\circ} 4$

$794-819$

Présence d'avocats influence-t-elle les résultats en arbitrage de grief? L'expérience de Terre-Neuve, La, Kenneth Wm. Thornicroft, $\mathrm{n}^{\circ} 2$

Private Service Sector, Determinants of Propensity to Unionize in the, Jean-Guy Bergeron, $\mathrm{n}^{\circ} 4$

Production allégée à l'usine CAMI, L'engagement du travailleur, les relations du travail et la, James Rinehart, Christopher Huxley et David Robertson, $n^{\circ} 4$

$792-794$

$773-776$

Propension à se syndiquer dans les services privés, Les facteurs explicatifs de la, Jean-Guy Bergeron, $\mathrm{n}^{\circ} 4$

$776-792$

Propension à travailler pour le syndicat, Aide demandée: Sarosh Kuruvilla et Jack Fiorito, $\mathrm{n}^{\circ} 3$

Propensity to Unionize in the Private Service Sector, Determinants of, Jean-Guy Bergeron, $\mathrm{n}^{\circ} 4$

Quebec Firms, Confidence, Cooperation and Partnership: A Process of Transformation in, Denis Harrisson and Normand Laplante, $n^{\circ} 4$.

Quebec Paper Industry, Recent Trends in Collective Bargaining in the, Reynald Bourque and Claude Rioux, $n^{\circ} 4$ 
Québec Labour Code, The Combined Effects of the New Québec Civil Code and the, Fernand Morin, $\mathrm{n}^{\circ} 2$

248-251

Québec Municipalities, The Determinants of Blue-Collar

Employees' Compensation in, Michel Tremblay and Denis Marcoux, $\mathrm{n}^{\circ} 3$

$545-548$

Québec, Perceptions et attitudes à l'égard des ressources humaines:

le cas de l'alimentation au détail au, René Blais, $\mathrm{n}^{\circ} 2$

$336-354$

Québec, Perceptions of and Attitudes Toward Human Resources:

Retail Food Sales in, René Blais, n 2

$354-356$

Québec, Tendances récentes de la négociation collective dans l'in-

dustrie du papier au, Reynald Bourque et Claude Rioux, $\mathrm{n}^{\circ} 4$.

Québec: A Diversity, Employers' Associations in the Province of,

François Delorme, Régis Fortin and Louis Gosselin, $\mathrm{n}^{\circ} 1 \ldots \ldots .$.

Québec: un portrait diversifié, L'organisation du monde patronal

$a u$, François Delorme, Régis Fortin et Louis Gosselin, $\mathrm{n}^{\circ} 1 \ldots$

Québécoises, Étude des déterminants de la rémunération des

employés manuels dans les municipalités, Michel Tremblay et

Denis Marcoux, $\mathrm{n}^{\circ} 3$

Recent Trends in Collective Bargaining in the Quebec Paper

Industry, Reynald Bourque and Claude Rioux, $\mathrm{n}^{\circ} 4$

$528-545$

$748-750$

Reinstatement in the Nonunion Sector: An Empirical Analysis,

Genevieve Eden, $\mathrm{n}^{\circ} 1$

$87-102$

Réintégration chez les non-syndiqués, La, Genevieve Eden, $\mathrm{n}^{\circ} 1 \ldots$

Relations du travail et la production allégée à l'usine CAMI,

L'engagement du travailleur, Les, James Rinehart, Christopher

Huxley et David Robertson, $n^{\circ} 4$

102-104

Relations industrielles à l'Université Laval, Un demi-siècle de,

Gilles Laflamme, $\mathrm{n}^{\circ} 1$

$730-748$

Relations professionnelles et gestion de l'emploi en France,

Décentralisation des, Liem Hoang-Ngoc et Michel Lallement, $n^{\circ} 3$

Rémunération des employés manuels dans les municipalités québécoises, Étude des déterminants de la, Michel Tremblay et Denis Marcoux, $\mathrm{n}^{\circ} 3$

Représentation syndicale selon la loi néo-zélandaise sur les contrats de travail : bilan après deux années, Négociations salariales et, Raymond Harbridge et Kevin Hince, $n^{\circ} 3$

Ressources humaines : le cas de l'alimentation au détail au Québec,

Perceptions et attitudes à l'égard des, René Blais, $n^{\circ} 2$

Restructuration économique: introduction, Syndicats et, Jacques

Bélanger et Gregor Murray, $n^{\circ} 4$ 
Restructuration en Grande-Bretagne depuis 1979 : les syndicats sur la défensive, Les politiques de, Jeremy Waddington et Colin Whitston, $\mathrm{n}^{\circ} 4$

Restructuration, Les dirigeants syndicaux et la crise économique: réponses à la restructuration, Les, Norene Pupo et Jerry White, $n^{\circ} 4$

Restructuring, Union Leaders and the Economic Crisis: Responses to, Norene Pupo and Jerry White, $\mathrm{n}^{\circ} 4$

Restructuring : Trade Unions on the Defensive in Britain Since 1979,

The Politics of, Jeremy Waddington and Colin Whitston, $\mathrm{n}^{\circ} 4$. Retail Food Sales in Québec, Perceptions of and Attitudes Toward Human Resources, René Blais, $\mathrm{n}^{\circ} 2$

Santé et sécurité au travail, Aspects économiques de la, Paul Lanoie, $\mathrm{n}^{\mathrm{o}} 1$

Satisfaction des clients, Décentralisation des services de ressources humaines: impacts sur la, Thierry Wils, Marcel Saint-Onge et Christiane Labelle, $\mathrm{n}^{\circ} 3$.

Services de ressources humaines: impacts sur la satisfaction des clients, Décentralisation des, Thierry Wils, Marcel Saint-Onge et Christiane Labelle, $\mathrm{n}^{\circ} 3$.

Services privés, Les facteurs explicatifs de la propension à se syndiquer dans les, Jean-Guy Bergeron, $\mathrm{n}^{\circ} 4$

Social Unionism, and Labour Movement Power in Canada and the

United States, NAFTA, Ian Robinson, $\mathrm{n}^{\circ} 4$

Substitution Between Unemployment Insurance and Workers'

Compensation, Paul Lanoie, $\mathrm{n}^{\circ} 1$

Syndicat, Aide demandée : propension à travailler pour le, Sarosh

Kuruvilla et Jack Fiorito, $\mathrm{n}^{\circ} 3$

Syndicats et les nouvelles formes d'organisation du travail, Les,

Paul-André Lapointe et Renaud Paquet, $\mathrm{n}^{\circ} 2$

Syndicats et restructuration économique: introduction, Jacques

Bélanger et Gregor Murray, $\mathrm{n}^{\circ} 4$....

Syndicats sur la défensive, Les politiques de restructuration en

Grande-Bretagne depuis 1979, Jeremy Waddington et Colin

Whitston, $\mathrm{n}^{\circ} 4$

Tarification par incidence - réactions des employeurs, La, Boris Kralj, $n^{\circ} 1$

Tendances récentes de la négociation collective dans l'industrie du papier au Québec, Reynald Bourque et Claude Rioux, $\mathrm{n}^{\circ} 4 \ldots$ Terre-Neuve, La présence d'avocats influence-t-elle les résultats en arbitrage de grief? L'expérience de, Kenneth Wm. Thornicroft, $\mathbf{n}^{\circ} 2$ 
Théorie intégrative de Wheeler lors de six élections syndicales, Une vérification de la, Hoyt $\mathrm{N}$. Wheeler, John A. McClendon et Roger D. Weikle, $\mathrm{n}^{\circ} 3$

Time to Certification of Unions in British Columbia, Richard Holmes and Robert Rogow, $\mathrm{n}^{\circ} 1$

Toward a Test of Wheeler's "Integrative Theory" in Six Union Election Cases, Hoyt N. Wheeler, John A. McClendon, and Roger D. Weikle, $\mathrm{n}^{\circ} 3$

Trade Unions on the Defensive in Britain Since 1979, The Politics of Restructuring, Jeremy Waddington and Colin Whitston, $n^{\circ} 4$. Transformation dans l'entreprise québécoise, Confiance, coopération et partenariat: un processus de, Denis Harrisson et Normand Laplante, $n^{\circ} 4$

696-728

Transformation in Quebec Firms, Confidence, Cooperation and Partnership: A Process of, Denis Harrisson and Normand Laplante, $n^{\circ} 4$.

$728-730$

Unemployment Insurance and Workers' Compensation, Substitution Between, Paul Lanoie, $\mathrm{n}^{\circ} 1$

Unemployment in Canada and the United States, Measures of Excess Demand and, Calvin D. Siebert and Mahmood A. Zaidi, $n^{\circ} 3$. Union Election Cases, Toward a Test of Wheeler's 'Integrative Theory" in Six, Hoyt N. Wheeler, John A. McClendon, and Roger D. Weikle, $\mathbf{n}^{\circ} 3$

Union Leaders and the Economic Crisis: Responses to Restructuring, Norene Pupo and Jerry White, $\mathrm{n}^{\circ} 4$

Union Officers' Policies on New Forms of Work Organization, Local, Paul-André Lapointe and Renaud Paquet, $\mathrm{n}^{\circ} 2$

Union, Who Will Help? Willingness to Work for the, Sarosh Kuruvilla and Jack Fiorito, $\mathrm{n}^{\circ} 3$

Unions and Economic Restructuring: Introduction, Jacques Bélanger and Gregor Murray, $n^{\circ} 4$

Unions in British Columbia, Time to Certification of, Richard Holmes and Robert Rogow, $\mathrm{n}^{\circ} 1$

United States, Measures of Excess Demand and Unemployment in

Canada and the, Calvin D. Siebert and Mahmood A. Zaidi, $\mathrm{n}^{\circ} 3$. United States, NAFTA, Social Unionism, and Labour Movement Power in Canada and the, Ian Robinson, $n^{\circ} 4$ $503-526$ $657-693$

Université Laval, A Half Century of Industrial Relations at, Gilles Laflamme, $\mathrm{n}^{\circ} 1$

Université Laval, Un demi-siècle de relations industrielles à l', Gilles Laflamme, $n^{\circ} 1$ 
Vérification de la théorie intégrative de Wheeler lors de six élections syndicales, Une, Hoyt N. Wheeler, John A. McClendon et Roger D. Weikle, $\mathrm{n}^{\circ} 3$

Vie familiale: une étude de cas des carrières des hommes et des femmes en gestion, Discrimination et, Alison M. Konrad et Kathy Cannings, $\mathrm{n}^{\circ} 2$

Wheeler lors de six élections syndicales, Une vérification de la théorie intégrative de, Hoyt $\mathrm{N}$. Wheeler, John $\mathrm{A}$. McClendon et Roger D. Weikle, $\mathrm{n}^{\circ} 3$

Wheeler's "Integrative Theory" in Six Union Election Cases, Toward a Test of, Hoyt N. Wheeler, John A. McClendon, and Roger D. Weikle, $\mathrm{n}^{\circ} 3$

Who Will Help? Willingness to Work for the Union, Sarosh Kuruvilla and Jack Fiorito, $n^{\circ} 3$

Women's Careers in Management, Of Mommy Tracks and Glass

Ceilings: A Case Study of Men's and, Alison M. Konrad and Kathy Cannings, $\mathrm{n}^{\circ} 2$

Work for the Union, Who Will Help? Willingness to, Sarosh Kuruvilla and Jack Fiorito, $\mathrm{n}^{\circ} 3$

$548-574$

Work Organization, Local Union Officers' Policies on New Forms of, Paul-André Lapointe and Renaud Paquet, $\mathrm{n}^{\circ} 2$ 302-303

Worker Commitment and Labour Management Relations under Lean Production at CAMI, James Rinehart, Christopher Huxley and David Robertson, $\mathrm{n}^{\circ} 4$

Worker Representation Under New Zealand's Employment

Contracts Legislation: A Review After Two Years, Bargaining and Worker, Raymond Harbridge and Kevin Hince, $\mathrm{n}^{\circ} 3$.

Workers' Compensation Insurance Experience Rating, Employer Responses to, Boris Kralj, $\mathrm{n}^{\circ} 1$

Workers' Compensation, Substitution Between Unemployment Insurance and, Paul Lanoie, $\mathrm{n}^{\circ} 1$

\section{Auteurs d'articles}

Authors of Articles

BÉLANGER, Jacques, Syndicats et restructuration économique : introduction, $\mathrm{n}^{\circ} 4$

BERGERON, Jean-Guy, Les facteurs explicatifs de la propension à se syndiquer dans les services privés, $\mathrm{n}^{\circ} 4$ 
BLAIS, René, Perceptions et attitudes à l'égard des ressources humaines : le cas de l'alimentation au détail au Québec, $\mathrm{n}^{\circ} 2$. BOURQUE, Reynald, Tendances récentes de la négociation collective dans l'industrie du papier au Québec, $\mathrm{n}^{\circ} 4$

$336-356$

$730-750$

BRIÈRE, Jean-Yves, Le Code civil du Québec et la Loi sur les normes du travail: convergence ou divergence?, $\mathrm{n}^{\circ} 1$

$104-133$

CANNINGS, Kathy, Of Mommy Tracks and Glass Ceilings : A Case Study of Men's and Women's Careers in Management, $\mathrm{n}^{\circ} 2 \ldots$

DELORME, François, L'organisation du monde patronal au Québec: un portrait diversifié, $\mathrm{n}^{\circ} 1$

303-336

EDEN, Genevieve, Reinstatement in the Nonunion Sector: An Empirical Analysis, $\mathrm{n}^{\circ} 1$

$87-104$

FIORITO, Jack, Who Will Help? Willingness to Work for the Union, $n^{\circ} 3$

$548-576$

FORTIN, Régis, L'organisation du monde patronal au Québec : un portrait diversifié, $\mathrm{n}^{\circ} 1$

GOSSELIN, Louis, L'organisation du monde patronal au Québec : un portrait diversifié, $\mathrm{n}^{\circ} 1$

GUÉRIN, Gilles, Facteurs explicatifs des intentions de quitter des cadres: l'importance de la carrière, $\mathrm{n}^{\circ} 1$

$152-160$

HARBRIDGE, Raymond, Bargaining and Worker Representation under New Zealand's Employment Contracts Legislation: A Review After Two Years, $\mathrm{n}^{\circ} 3$

$576-597$

HARRISON, Denis, Confiance, coopération et partenariat : un processus de transformation dans l'entreprise québécoise, $n^{\circ} 4 \ldots$.

HINCE, Kevin, Bargaining and Worker Representation under New Zealand's Employment Contracts Legislation: A Review After Two Years, $\mathbf{n}^{\circ} 3$

$576-597$

HOANG-NGOC, Liem, Décentralisation des relations professionnelles et gestion de l'emploi en France, $\mathrm{n}^{\circ} 3$

$441-465$

HOLMES, Richard, Time to Certification of Unions in British Columbia, $\mathrm{n}^{\circ} 1$

HUXLEY, Christopher, Worker Commitment and Labour Management Relations under Lean Production at CAMI, $\mathrm{n}^{\circ} 4$.

KELLER, Berndt, The German Version of Deregulation - and Beyond, $\mathrm{n}^{\circ} 2$

$750-776$

$251-281$

KONRAD, Alison M., Of Mommy Tracks and Glass Ceilings : A Case Study of Men's and Women's Careers in Management, $n^{\circ} 2$

KRALJ, Boris, Employer Responses to Workers' Compensation Insurance Experience Rating, $\mathrm{n}^{\circ} 1$ 
KURUVILLA, Sarosh, Who Will Help? Willingness to Work for the Union, $\mathrm{n}^{\circ} 3$

$548-576$

LABELLE, Christiane, Décentralisation des services de ressources humaines: impacts sur la satisfaction des clients, $\mathrm{n}^{\circ} 3$

$483-503$

LAFLAMME, Gilles, Un demi-siècle de relations industrielles à l'Université Laval, $\mathrm{n}^{\circ} 1$

LALLEMENT, Michel, Décentralisation des relations professionnelles et gestion de l'emploi en France, $\mathrm{n}^{\circ} 3$

$441-465$

LANOIE, Paul, Aspects économiques de la santé et sécurité au travail, $\mathrm{n}^{\circ} 16$

LAPLANTE, Normand, Confiance, coopération et partenariat : un processus de transformation dans l'entreprise québécoise, $\mathrm{n}^{\circ} 4$.

LAPOINTE, Paul-André, Les syndicats et les nouvelles formes d'organisation du travail, $\mathrm{n}^{\circ} 2$

MARCOUX, Denis, Étude des déterminants de la rémunération des employés manuels dans les municipalités québécoises, $\mathrm{n}^{\circ} 3 \ldots$.

McCLENDON, John A., Toward a Test of Wheeler's 'Integrative Theory" in Six Union Election Cases, $\mathrm{n}^{\circ} 3$

MORIN, Fernand, Effets combinatoires de deux codes : Code du travail et Code civil du Québec, $\mathrm{n}^{\circ} 2$

$696-730$

$281-303$

$528-548$

$465-483$

$227-251$

MURRAY, Gregor, Syndicat et restructuration économique : introduction, $\mathrm{n}^{\circ} 4$

PAQUET, Renaud, Les syndicats et les nouvelles formes d'organisation du travail, $\mathrm{n}^{\circ} 2$.

$281-303$

PUPO, Norene, Union Leaders and the Economic Crisis : Responses to Restructuring, $\mathrm{n}^{\circ} 4$

RINEHART, James, Worker Commitment and Labour Management Relations under Lean Production at CAMI, $\mathrm{n}^{\circ} 4$

$821-846$

$750-776$

RIOUX, Claude, Tendances récentes de la négociation collective dans l'industrie du papier au Québec, $\mathrm{n}^{\circ} 4$

ROBERTSON, David, Worker Commitment and Labour Management Relations under Lean Production at CAMI, $\mathrm{n}^{\circ} 4$.

ROBINSON, Ian, NAFTA, Social Unionism, and Labour Movement Power in Canada and the United States, $n^{\circ} 4$

ROGOW, Robert, Time to Certification of Unions in British Columbia, $\mathrm{n}^{\circ} 1$

SABA, Tania, Facteurs explicatifs des intentions de quitter des cadres: l'importance de la carrière, $\mathrm{n}^{\circ} 1$

SAINT-ONGE, Marcel, Décentralisation des services de ressources humaines: impacts sur la satisfaction des clients, $\mathrm{n}^{\circ} 3$.

SIEBERT, Calvin D., Measures of Excess Demand and Unemployment in Canada and the United States, $\mathrm{n}^{\circ} 3$ 
THORNICROFT, Kenneth Wm., Do Lawyers Affect Grievance Arbitration Outcomes? The Newfoundland Experience, $\mathrm{n}^{\circ} 2 \ldots$ TREMBLAY, Michel, Étude des déterminants de la rémunération des employés manuels dans les municipalités québécoises, $\mathrm{n}^{\circ} 3$ WADDINGTON, Jeremy, The Politics of Restructuring: Trade Unions on the Defensive in Britain Since 1979, $\mathrm{n}^{\circ} 4$

$356-372$

$528-548$

$794-821$

WEIKLE, Roger D., Toward a Test of Wheeler's 'Integrative Theory" in Six Union Election Cases, $\mathrm{n}^{\circ} 3$

WHEELER, Hoyt N., Toward a Test of Wheeler's "Integrative Theory" in Six Union Election Cases, $\mathrm{n}^{\circ} 3$

WHITE, Jerry, Union Leaders and the Economic Crisis: Responses to Restructuring, $\mathrm{n}^{\circ} 4$

WHITSTON, Colin, The Politics of Restructuring : Trade Unions on the Defensive in Britain Since 1979, $\mathrm{n}^{\circ} 4$.

794-821

WILS, Thierry, Décentralisation des services de ressources humaines: impacts sur la satisfaction des clients, $\mathrm{n}^{\circ} 3 \ldots \ldots \ldots . . .$.

WILS, Thierry, Facteurs explicatifs des intentions de quitter des cadres: l'importance de la carrière, $\mathrm{n}^{\circ} 1$

ZAIDI, Mahmood A., Measures of Excess Demand and Unemployment in Canada and the United States, $\mathrm{n}^{\circ} 3$.

503-528

\section{Auteurs des ouvrages recensés}

\section{Authors of Books Reviewed}

Adams, Roy J., ed., Industrial Relations Theory: Its Nature, Scope, and Pedagogy (Jean Boivin, Mark Thompson, Richard B. Peterson and Jean Boivin), $\mathrm{n}^{\circ} 2$

$379-402$

Aggarwal, Arjun P., Sexual Harassment in the Workplace (P. Andiappan), $n^{\circ} 1$

204-205

Bamber, Greg J., ed., International and Comparative Industrial Relations: A Study of Industrialised Market Economies (Hans Slomp), $\mathrm{n}^{\circ} 3$

$604-606$

Bernier, Colette, dir., La négociation collective du travail : adaptation ou disparition? (Renaud Paquet et Jean-Guy Bergeron), $\mathrm{n}^{\circ} 1$

Bosch, Gerhard, Retraining - Not Redundancy. Innovative Approaches to Industrial Restructuring in Germany and France (Christoph F. Buechtemann), $\mathrm{n}^{\mathrm{o}} 1$.... 
Broad, Mary L., Transfer of Training : Action-Packed Strategies to Ensure High Payoff from Training Investments (Victor Haines), $\mathrm{n}^{\circ} 1$

197-199

Brown, Richard K., Understanding Industrial Organisations: Theoritical Perspectives in Industrial Sociology (Denis Harrisson), $n^{\circ} 4$

Burton, Cynthia E., Mutual Gains. A Guide to Union-Management Cooperation (Colette Bernier), $\mathrm{n}^{\circ} 2$

Cohen-Rosenthal, Edward, Mutual Gains. A Guide to UnionManagement Cooperation (Colette Bernier), $\mathrm{n}^{\circ} 2$

Craig, Alton W.J., The System of Industrial Relations in Canada (David C. McPhillips), $\mathrm{n}^{\circ} 4$

Craypo, Charles, Grand Designs: The Impact of Corporate Strategies on Workers, Unions, and Communities (Dale Bleman), $n^{\circ} 3$

$865-869$

$406-408$

$406-408$

$856-858$

$606-608$

Daigle, Gérard, dir., Le Québec en jeu : comprendre les grands défis (Bernard Solasse), $n^{\circ} 3$

Dandurand, Pierre, dir., Enjeux actuels de la formation professionnelle (Marie-Thérèse Chicha), ${ }^{\circ} 4$

$858-861$

DeBresson, Christian, Comprendre le changement technique (Martin Dumas), $\mathrm{n}^{\circ} 1$

Friedberg, Erhard, Le Pouvoir et la Règle. Dynamiques de l'action organisée (Stéphane Le Queux), $\mathrm{n}^{\circ} 2$

$202-204$

$411-415$

Gortner, Harold F., La gestion des organisations publiques (JeanMarie Rainville), $n^{\circ} 4$

$863-865$

Gould IV, W.B., A Primer on American Labor Law (Pierre Verge), $\mathrm{n}^{\circ} 3$.

608-609

Guérin, Gilles, La gestion des ressources humaines : du modèle traditionnel au modèle renouvelé (Michel Audet, Laurent Bélanger, Richard J. Long et Bernard Galambaud), $\mathrm{n}^{\circ} 1$

Kaufman, Bruce E., The Origins and Evolution of the Field of Industrial Relations in the United States (Noah M. Meltz), $\mathrm{n}^{\circ} 2$. Kent, Ronald C., ed., Culture, Gender, Race and U.S. Labor History (Charles J. McCollester), $n^{\circ} 4$

Kruse, Douglas L., Profit Sharing: Does it Make a Difference? (Richard J. Long), $\mathrm{n}^{\circ} 4$.

Kumar, Pradeep, From Uniformity to Diversity : Industrial Relations in Canada and the United States (Joseph B. Rose), $\mathrm{n}^{\circ} 2$

Laflamme, Roch, dir., La négociation collective du travail : adaptation ou disparition? (Renaud Paquet et Jean-Guy Bergeron), $n^{\circ} 1$

$168-188$

$402-404$

$869-872$

$861-863$

$404-406$

$188-190$ 
Lallemant, Michel, Histoire des idées sociologiques, Tome 1: Des origines à Weber; Tome 2: De Parsons aux contemporains (Yves Laberge), $\mathrm{n}^{\circ} 3$

Lansbury, Russell D., ed., International and Comparative Industrial Relations : A Study of Industrialised Market Economies (Hans Slomp), $\mathrm{n}^{\circ} 3$.

Laporte, Pierre, Travail plus. Le travail et vos droits (Diane Veilleux), $\mathrm{n}^{0} 2$.

604-606

Leclerc, Michel, Les relations du travail au Québec: une analyse de la situation dans le secteur public (Jean Boivin), $\mathrm{n}^{\circ} 2$

$408-411$

Mahler, Julianne, La gestion des organisations publiques (JeanMarie Rainville), $n^{\circ} 4$

$863-865$

Markham, Sara, ed., Culture, Gender, Race and U.S. Labor History (Charles J. McCollester), $n^{\circ} 4$

$869-872$

Meltz, Noah M., ed., Industrial Relations Theory: Its Nature, Scope, and Pedagogy (Jean Boivin, Mark Thompson, Richard B. Peterson and Jean Boivin), $\mathrm{n}^{\circ} 2$

$379-402$

Meltz, Noah M., Human Resource Management in Canada (Denis Morin), $n^{\circ} 1$

Metcalf, David, ed., New Perspectives on Industrial Disputes (P. B. Beaumont), $\mathrm{n}^{\circ} 3$

Milner, Simon, ed., New Perspectives on Industrial Disputes (P.B. Beaumont), $\mathrm{n}^{\circ} 3$

Morin, Fernand, dir., La négociation collective du travail : adaptation ou disparition? (Renaud Paquet et Jean-Guy Bergeron), $\mathrm{n}^{\circ} 1$

Murray, Gregor, dir., La négociation collective du travail : adaptation ou disparition? (Renaud Paquet et Jean-Guy Bergeron), $\mathrm{n}^{\circ} 1$

Newstrom, John W., Transfer of Training : Action-Packed Strategies to Ensure High Payoff from Training Investments (Victor Haines), $\mathrm{n}^{\circ} 1$

Nicholson, Jeanne Bell, La gestion des organisations publiques (Jean-Marie Rainville), $\mathrm{n}^{\circ} 4$

Nissen, Bruce, Grand Designs: The Impact of Corporate Strategies on Workers, Unions, and Communities (Dale Belman), $\mathrm{n}^{\circ} 3 \ldots$ Ouimet, Hélène, Travail plus. Le travail et vos droits (Diane Veilleux), $\mathrm{n}^{\circ} 2$.

606-608

Puette, William J., Through Jaundiced Eyes: How the Media View Organized Labor (Anil Verma), $\mathrm{n}^{\circ} 1$

Quimper, Michel, Les relations du travail au Québec: une analyse de la situation dans le secteur public (Jean Boivin), $\mathrm{n}^{\circ} 2 \ldots \ldots . .$. 
Quinlan, M., ed., Work and Health (Eric Tucker), $\mathrm{n}^{\circ} 2$

$416-420$

Rocher, Guy, coll., Le Québec en jeu : comprendre les grands défis (Bernard Solasse), $\mathrm{n}^{\circ} 3$

Roediger, David R., ed., Culture, Gender, Race and U.S. Labor History (Charles J. McCollester), $n^{\circ} 4$

$611-613$

$869-872$

Rondeau, Claude, dir., La négociation collective du travail : adaptation ou disparition? (Renaud Paquet et Jean-Guy Bergeron), $\mathrm{n}^{\circ}$ 1 .

Shapiro, Herbert, ed., Culture, Gender, Race and U.S. Labor History (Charles J. McCollester), ${ }^{\circ} 4$

Solomon, Norman A., The System of Industrial Relations in Canada (David C. McPhillips), ${ }^{\circ} 4$ $856-858$

Stone, Thomas H ., Human Resource Management in Canada (Denis Morin), $\mathrm{n}^{\circ} 1$

Wils, Thierry, La gestion des ressources humaines : du modèle traditionnel au modèle renouvelé (Michel Audet, Laurent Bélanger, Richard J. Long et Bernard Galambaud), $n^{\circ} 1$.

$168-188$

\section{Changements dans la législation du travail au Canada Changes in Canadian Labour Laws}

$1^{\text {er }}$ juillet au 30 septembre $1993, \mathrm{n}^{\circ} 1$

$160-168$

$1^{\text {er }}$ octobre au 31 décembre $1993, \mathrm{n}^{\circ} 2$ $372-379$

$1^{\text {er }}$ janvier au 31 mars $1994, n^{\circ} 3$ 597-604

$1^{\text {er }}$ avril au 30 juin $1994, n^{\circ} 4$ 846-856 